\title{
Challenges of Wood Modification Process for Plantation Eucalyptus: A Review of Australian Setting ${ }^{1}$
}

\author{
Ros Syazmini Mohd GHANI(D ${ }^{2, \uparrow} \cdot$ Man Djun LEE $^{3}$
}

\begin{abstract}
Australia has significant wood resources in its native forest, but the resource available for harvest becomes lesser due to the conversion of native forest to conservation reserves. The natural occurrences of bushfires, droughts, and cyclones are highly destructive, making the situation worse. The shortage of wood resources is having a significant negative impact on Australia because wood is so scarce that they cannot meet domestic demands, especially durable wood. Australia cleared approximately 100 million hectares of its land to establish forest plantations, and two million trees were planted. However, most of these plantations are for pulpwood production; however, their application for high-value products is limited due to their undesirable properties. Wood modification is a process of improving unfavorable wood properties to be utilized for a wide range of applications. Australia has not adopted any of these modification processes; it still depends on the less toxic wood preservative to treat wood. This study focuses on the recent advancement in industrial wood modification worldwide and how it may be used to modify Eucalyptus wood for high-value applications. The opportunities and suggestions for Eucalyptus wood modification in Australia will be discussed. Before the study concludes, the future of commercial wood modification for Eucalyptus plantation in Australia will also be presented.
\end{abstract}

Keywords: modified wood, feasibility study, Eucalyptus, australia wood industry, plantation wood

\section{INTRODUCTION}

In 1997, the Australian government announced the 2020 vision in which the forest plantation is targeted to expand to three million hectares by that year. The forest plantation resources intend to become the import replacement to replace imported timber that would benefit the country and support jobs in regional
Australia. It also aims to replace the logs from the native forest with plantation resources so that more forests can be set aside in the conservation reserved (Brown \& Beadle 2008). Nonetheless, by 2019, Australia only has an estimated two million hectares of plantation forest with equal percentages of softwoods and hardwoods. The softwood plantations are composed of over $75 \%$ Pinus radiata, while Eucalyptus species dom-

${ }^{1}$ Date Received December 28, 2020, Date Accepted March 9, 2021

2 Department of Mechanical Engineering, School of Engineering and Technology, University College of Technology Sarawak, Sibu, Sarawak, Malaysia

${ }^{3}$ Department of Mechanical Engineering, Faculty of Engineering and Science, Curtin University, Miri, Sarawak, Malaysia

$\dagger$ Corresponding author: Ros Syazmini Mohd GHANI (e-mail: ros.syazmini@ucts.edu.my, ORCID: 0000-0002-0015-5606) 
inate the hardwood plantations. Hardwood plantations in Australia are dominated by Eucalyptus globulus (51.1\%) and Eucalyptus nitens (26.1\%) (Downham \& Gavran 2019).

Currently, the plantation forest provides $70 \%$ of Australia's domestically produced wood products, with the remaining coming from the native forest (ABARES 2018). Softwood saw logs are harvested for domestic use to produce sawn wood for residential construction and furniture manufacturing. They also produce lower-grade pulpwood as a by-product of thinning and final harvest. In contrast, almost all hardwood plantation in Australia is managed for pulp log production.

In Australia, softwood plantation has remained unchanged over the last twenty years, but the hardwood plantation area proliferates at the same period in which tripling in size. While this hardwood resource is still young, the growing supply of plantation hardwood represents an opportunity to increase the wood value beyond log, veneer, pulp, and paper production. Besides, with decreasing log supplies and loss of native forest for forest plantations, there is an increasing interest in developing E. globulus and E. nitens to produce high-value sawn wood (Tepper, 2007; Beadle et al., 2008). However, since the Eucalyptus wood is planted mainly for pulpwood production, these resources have inferior wood properties, such as regular knots, collapse during drying, high radial and tangential shrinkage rate, cracks and/or splits due to growth stresses released during cutting, sawing and drying (Ahmer et al., 2019; Derikvand et al., 2017, Unsal et al., 2011). Hence, researchers are interested in exploring the ability of Eucalyptus to be produced as modified wood, for example, densified wood, polymer-impregnated wood, thermally modified wood, and acetylated wood to overcome the low-wood properties. The considerable increase in research on wood modification in Australia in recent years is driven by the uncertain supply of durable wood, the desire to move away from traditional heavy-metal-based preservatives, and the need to address the unfavourable properties of plantation species.

This review aims to discuss the challenges and opportunities in developing wood modification in Australia for plantation Eucalyptus. The main issues addressed in this paper are a) the challenges in adopting wood modification in Australia based on the current commercial modification technologies and relationship with plantation resources in Australia, b) research and development on wood modification in Australia, c) product development of potential wood modification in Australia, and d) the future of industrial wood modification process in Australia. From a broader perspective, this review paper gives an insight into how the challenges in adopting wood modification elsewhere, not only in Australia, can be overcome. A similar situation is happening worldwide with the increasing demand for sustainable high-value products from hardwoods, but the supply is insufficient. Therefore, adopting the wood modification process should be the focus in every country around the world.

\subsection{Australian Wood Resources}

The increasing interest in using Eucalyptus wood to produce high-value sawn wood is due to the decreasing log supplies and loss of native forest for forest plantations (Tepper, 2007; Beadle et al., 2008). However, only $18 \%$ of hardwood plantations in Australia manage to produce wood, mainly to supplement the native forest timber production, especially for products like flooring and structural wood. The remaining resources are planted with a short rotation between 12 to 20 years for pulp log production. Nevertheless, the supply of sawlogs from plantations is projected to increase by 2030. For example, Sustainable Timber Tasmania (STT) intends to supply around $150,000 \mathrm{~m}^{3}$ of hardwood sawlogs annually by 2025 , and the sup- 
ply is enough until 2094 (Wood et al., 2009).

Innes et al. (2007) studied the economics of plantation Eucalyptus for solid wood products and suggested a few significant findings. Firstly, the value of solid wood from thinned and pruned E. globulus logs and $\operatorname{logs}$ salvaged from the fibre-managed $E$. nitens is enough for the grower and processor to make a considerable profit. However, the growing and processing of thinned and pruned E. nitens were unprofitably caused by the loss of material from internal checking, especially the butt log. There is also a considerable loss in the wood output resulting from the internal check in E. nitens and board distortion in E. globulus. Thus, the report justifies why the plantation industry players are disinterested in producing solid wood from

\section{Eucalyptus wood.}

Most of the modification process requirements are timber with long and clear length because of the concern with knots that might affect the properties variation and appearance. There is also evidence suggesting that stiffness and strength loss are unreasonably high around knots. Modification process like ThermoWood ${ }^{\circledR}$ and Kebony ${ }^{\circledR}$ utilize wood from self-pruning trees, for instance, Picea sp. Eucalyptus is commonly self-pruning, but in plantations, it is grown under different conditions causing unfavourable self-pruning. Most of the hardwood plantation resources are managed for fibre in which the stands are unthinned causing the presence of knots on the plantation resources inevitable. Thus, there is a concern of a limited supply of clear wood for continuous feed material if the modification process is adopted (Washusen et al., 2004; Nolan et al., 2005).

\subsection{Wood Properties}

A wood modification process may affect the wood in a few ways, but the process is often developed according to the wood properties and target end-use (Rowell, 2007). Wood quality is the primary concern for fast-grown plantation wood, especially for solid wood production. However, in Australia, wood properties that affect the solid wood production from plantation Eucalyptus wood are less understood than the resources from native forest Eucalyptus. Modified wood seeks to address a broader performance scope other than durability, with dimensional stability in service life as a critical focus. This paper focuses on three critical properties that need to be modified from plantation Eucalyptus in Australia: dimensional instability, durability, and fire retardancy.

\subsubsection{Dimensional stability}

Improving dimensional stability is one of the primary objectives of wood modification, especially in applications with lower moisture risk but with high requirements for exact and constant dimensions, such as for structural materials. In many wood applications, improving dimensional stability will also reduce crack formation, thus keeping the water from the material (Homan and Jorissen, 2004). This is important to retain the durability of the material. The fundamental idea of dimensional stability improvement by wood modification is altering how wood interacts with water (Sargent, 2019).

Dimensional instability is one of the common problems with fast-growing hardwoods (Priadi et al., 2019). Trees that are cut at a younger age have a large portions of sapwood, juvenile wood, and tension wood that have inferior characteristics compared to wood from mature trees (Hadi et al., 2019). Besides, since most of these Eucalyptus plantations in Australia are established to supply fibre for pulpwood production, the Eucalyptus stands have not been thinned and pruned to maximize the output and reduce cost (Beadle et al., 2009; Nichols et al., 2010). As a result, this timber contains a high percentage of features like knots, limb trace, and gum vein (Derikvand et al., 2017).

Juvenile wood is a plant tissue formed by the immature cambial meristem, and compared to mature 
wood, juvenile wood has smaller cells, shorter fibres, thinner cell walls, and higher cellulose microfibrillar angle with lower density, strength, and stiffness (Balboni et al., 2020). The transition from juvenile to mature wood could take around 6 to 15 years or up to 20 years depending on the species, meaning that trees grown in short-rotation plantations contain a high percentage of juvenile wood. In contrast, tension wood occurs due to the bending or leaning of trees in response to environmental stimuli such as wind or light, which cause poor drying performance of the wood, and the stress release of the wood during sawing will cause excessive distortion, splitting, and low sawing accuracy (Washusen et al., 2005).

\subsubsection{Durability}

Australia's harsh environment and voracious insect life mean most of the timber in the Australian market are either chemically treated or naturally high durability. Durability of timber is defined as the natural resistance to biodeterioration caused by fungi, insects, and mechanical breakdowns like weathering, checking, and splitting. Durable wood is highly desirable for functions unprotected from weather or insect attack, especially termites (Nolan et al., 2005). Termites attack on timber products in Australia is very severe, with subterranean termites being a highly damaging timber pest causing significant damage to the structural timber of buildings in Australia. The attack is so severe that they are known to damage the wall and roofing timbers of a house within three months of construction and cause more destruction to Australia's homes than fire, floods, storms, and tempest, combined.

According to National Construction Code (NCC), wood for structural application must comply with the $\mathrm{H} 3$ standard of durability in Australian Standard AS1604. This hazard classifies for outside, above-ground exposure subject to periodic moderate wetting and leaching and moderate decay, borers, and termite attack. In Australia, only less than $5 \%$ of the Eucalyptus plantation is planted with high natural durability (class 1 or 2) with a probable in-ground life expectancy of at least 15 years according to Australia Standard 5604 because the main hardwood plantation species in Australia are generally non-durable. E. nitens is classified as Class 3 (life expectancy between 7 to 15 years) and Class 4 (life expectancy less than five years) respectively, for above ground and in-ground applications. They are also vulnerable to termites, and their sapwood is susceptible to Lyctid borers. In comparison, E. globulus is Class 2 (life expectancy between 15 to 40 years) and Class 3 , respectively, for above ground and inground applications.

There are several ways wood modification can help to increase wood durability. Firstly, wood modification can lower the moisture content in the wood, in which high moisture content is favourable for the bio-deterioration agent attack. Secondly, the wood modification will increase the dimensional stability of the wood, reducing the possibility of cracks or splits, which would be the insect's entrance. Thirdly, modifying the wood's chemical content by reducing certain chemical content, especially cellulose, that serves as the bio-deterioration agent's food.

\subsubsection{Fire resistance}

Fire retardant material is vital in Australia as Australia is one of the most bushfire-prone countries. Regardless of the strict precautions and total fire ban days, widespread seasonal grass and bushfires occur frequently. During the 2019-2020 Australian summer bushfires, around 2,000 houses were lost to the fire. The Australian bushfire standard aims to decrease the risk of property destruction due to bushfires or wildfires. It states that the fire-retardant wood should not ignite when exposed to a radiation of $10 \mathrm{~kW} \mathrm{~m}$ in an oxygen consumption calorimeter. When tested in a cone calorimeter at an irradiance level of $25 \mathrm{~kW}$ $\mathrm{m}^{-2}$, the maximum heat release rate should not be more 
than $100 \mathrm{~kW} \mathrm{~m}^{-2}$, and the average heat release rate for 10 min after ignition should be less than $60 \mathrm{~kW} \mathrm{~m}^{-2}$.

E. nitens and E. globulus are considered slightly combustible (Class 3) in the fire property group number. Therefore, this wood needs to undergo wood modification to increase its fire retardancy approved by NCC to be used in a structural application. Overall, all modification treatment does not improve the fire resistance of the modified wood. However, adding additives, such as boron, can improve the fire performance in ThermoWood ${ }^{\circledR}$. Besides that, there is also a potential to pair other modification processes with fire retardant substances to achieve more excellent fire resistance in wood (Jiang et al., 2014).

\section{THE CHALLENGES of WOOD MODIFICATION in AUSTRALIA}

There have been industrial operations globally since the 1930s to produce modified wood for niche markets (Hill, 2007; Lahtela et al., 2014). However, none of these processes had received much attention due to the stable supply of durable wood (Esteves and Pereira 2009). Later, in the mid-1990s, there was a rapid growth in the research, development, and adoption of wood modification technologies. It indicates the increasing interest in sustainable products and consumer demand for high performance and low maintenance products. The renewed interest in wood modification technologies is also caused by increasing awareness of the environment's fragility with new technologies developed to increase the wood service life without applying toxic chemicals (Townsend and Solo-Gabriele 2006; Mantanis and Şahin 2017).

Wood modification is a method to enhance wood characteristics to produce a new material that, when discarded at the end of its life cycle, would not cause any environmental hazard higher than the unmodified wood (Hill 2007). The wood properties that can be improved are dimensional stability, resistance to biological degradation, thermal stability, fire resistance, U.V. resistance, and mechanical characteristics (Rowell 2005). There are three significant types of wood modification process: thermal, chemical, and impregnation modifications. Each modification process has advantages and disadvantages according to the modified wood characteristics and the modification process intricacy (Hill 2011). Thermal modification is useful to improve dimensional stability and durability, and a chemical modification, that is externally applied chemical reagent effectively reduces hygroscopicity. In contrast, impregnation does not alter cell wall polymers' molecular structure but can increase wood density and block water pathways (Ramage et al., 2017).

Currently, there are a few modification processes that are successfully commercialized which are ThermoWood $^{\circledR}$, Plato ${ }^{\circledR}$ and oil heat treatment (OHT) (thermal modification), Accoy $\mathrm{a}^{\circledR}$ that are originated from the acetylation process (chemical modification) and VisorWood ${ }^{\circledR}$ and Kebony ${ }^{\circledR}$ that are from the furfurylation process (impregnation modification). Table 1 summarises the origin, output, and methods of the five main commercial wood modifications worldwide.

Despite the interest in modified wood, the total number of modified wood produced globally is still insignificant compared to the conventional treated wood, which is the wood that is treated by using preservatives. Hence, industrial wood modification technologies are still considered embryonic in the wood industry, even after ten to twenty years of commercialization (Dunningham and Sargent, 2015). This can be observed in Australia, whereby the local wood industry is still not moving away from using a heavy metal-based preservative, like copper chromium arsenate (CCA) and other lower toxicity preservatives are considered safe. Militz (2020) suggests other possible reasons for this slow growth of wood modification, including consumer perception, unknown properties, 
Table 1. The five primary commercialized wood modification process

\begin{tabular}{|c|c|c|c|}
\hline $\begin{array}{l}\text { Wood } \\
\text { modification } \\
\text { process }\end{array}$ & $\begin{array}{l}\text { Developer/ } \\
\text { country }\end{array}$ & Application & Process \\
\hline ThermoWood $^{\circledR}$ & $\begin{array}{l}\text { Finnish } \\
\text { Research Centre } \\
\text { (Esteves and } \\
\text { Pereira 2009) }\end{array}$ & $\begin{array}{l}80 \% \text { are for cladding } \\
\text { and decking, internal } \\
\text { wall and ceiling panels, } \\
\text { and internal flooring } \\
\text { (Ala-Viikari and Mayes } \\
2009 \text { ) }\end{array}$ & $\begin{array}{l}\text { Phase 1: Warming up } \\
\text { - Wood heating and pre-drying in which the kiln temperature is } \\
\text { quickly increased and produce steam. } \\
\text { Phase 2: Drying } \\
\text { - Temperature is raised gradually, and timber is dry until the } \\
\text { moisture content reaches near } 0 \% \text {, and the temperature is } \\
\text { increased to } 185^{\circ}-215^{\circ} \mathrm{C} \text { for } 2-3 \text { hours, depending on its } \\
\text { application. } \\
\text { Phase 3: Cooling and conditioning } \\
\text { - The wood temperature is decreased to } 80^{\circ}-90^{\circ} \mathrm{C} \text { by using water } \\
\text { spray systems. Conditioning is carried out to moisten the } \\
\text { heat-treated wood between } 4-7 \% \text { (Shi et al., 2007; Gérardin, } \\
\text { 2016). }\end{array}$ \\
\hline Plato $^{\circledR}$ & $\begin{array}{l}\text { Plato BV, } \\
\text { Netherlands }\end{array}$ & $\begin{array}{l}\text { Claddings, garden } \\
\text { fences and furniture, } \\
\text { poles and sheds and in } \\
\text { canal linings and jetty } \\
\text { (Homan et al., 2000) }\end{array}$ & $\begin{array}{l}\text { Step 1: Hydrothermolysis process for } 4-5 \text { hours at } 160^{\circ}-190^{\circ} \mathrm{C} \\
\text { in humid conditions and above atmospheric pressure. } \\
\text { Step 2: Wood drying until } 10 \% \text { equilibrium moisture for } 3-5 \text { days. } \\
\text { Step 3: Reheating the wood at } 170^{\circ}-190^{\circ} \mathrm{C} \text { for } 14-16 \text { hours } \\
\text { in dry condition. } \\
\text { Step 4: Increase the wood equilibrium moisture to normal process } \\
\text { conditions. The treatment duration varies according to the species, } \\
\text { thickness, shape, and final product. Hot vapour or heated air is } \\
\text { used as a heating medium (Militz, 2002; Gérardin, 2016). }\end{array}$ \\
\hline $\begin{array}{l}\text { Oil heat } \\
\text { treatment } \\
(\mathrm{OHT})\end{array}$ & $\begin{array}{l}\text { MENZ HOLZ, } \\
\text { Reulbach, } \\
\text { Germany }\end{array}$ & Garden furniture & $\begin{array}{l}\text { Hot oil (rapeseed oil, linseed oil, or sunflower oil) is introduced } \\
\text { in a closed vessel with green wood and treated for } 2-4 \text { hours, } \\
\text { with } 18 \text { hours in total, including the heating and cooling phase } \\
\text { (Rapp and Sailer 2000; Gérardin, 2016). }\end{array}$ \\
\hline Accoya ${ }^{\circledR}$ & $\begin{array}{l}\text { Accsys } \\
\text { Technologies, } \\
\text { Arnhem, } \\
\text { Netherlands }\end{array}$ & $\begin{array}{l}\text { Exterior for window } \\
\text { and door, decking, } \\
\text { cladding, and civil } \\
\text { construction, especially } \\
\text { outdoors, above- and } \\
\text { in-ground contact } \\
\text { (Mantanis, 2017) }\end{array}$ & $\begin{array}{l}\text { The standard procedure is by using acetic anhydride containing a } \\
\text { small amount of acetic acid without a catalyst. Heat is applied using } \\
\text { microwaves or conventional heating (Rowell, 2006). The reaction } \\
\text { of acetic anhydride with wood polymers resulting in the } \\
\text { esterification of the free hydroxyl group in the cell wall with the } \\
\text { formation of acetic acid as by-products, which are usually } \\
\text { eliminated as the human nose is sensitive to its smell and it is } \\
\text { highly corrosive to ferrous fastenings (Hill, 2011; Mantanis, 2017). }\end{array}$ \\
\hline $\begin{array}{l}\text { VisorWood }^{\circledR} \\
\text { and Kebony }\end{array}$ & $\begin{array}{l}\text { Kebony ASA, } \\
\text { Norway }\end{array}$ & $\begin{array}{l}\text { Construction materials } \\
\text { (Lande et al., 2008) }\end{array}$ & $\begin{array}{l}\text { Step 1: The treating solutions are mixed in a mixing tank that } \\
\text { consists of furfuryl alcohol, inhibitor, buffering agents, surfactants, } \\
\text { and water before the solution is pumped into the buffer tanks. } \\
\text { Step 2: The wood is vacuum pressure impregnated with the treating } \\
\text { solution by a full-cell process with a vacuum step, pressure step, } \\
\text { and a short post-vacuum step. } \\
\text { Step 3: In-situ polymerization of the chemicals and grafting } \\
\text { reactions with the polymeric wood components. The curing } \\
\text { chamber is heated with direct-injected steam, in which the } \\
\text { temperature depends on the wood species. The chamber worked } \\
\text { as a closed system during the curing period except for ventilation } \\
\text { at the end of the process. } \\
\text { Step 4: Wood drying in kiln-dryer to achieve final moisture content } \\
\text { (Mantanis, 2017). }\end{array}$ \\
\hline
\end{tabular}


higher price and lack of experience using the new material.

When considering wood modification technologies, it is essential to consider that wood structure and chemistry can be effectively improved and manipulated during the process and consider the limits presented due to anatomical differences between wood species. This review paper considers the challenges in economics, environmental, and barriers to adoption of wood modification technologies.

\subsection{Economics}

Financial is one of the reasons that were slowing down the commercialization process of wood modification in Australia. Jones (2007) and Militz (2020) outlined the reasons for the inability of wood modification to be commercialized. Among them are too high market entry price, the high investment cost of specialized equipment, incomplete market survey, and insufficient technology.

Thus, it is crucial to review the economics of the readily available commercial wood modification process. The wood modification process can be quickly adopted if the process is considered economically viable, including low cost of plant set-up, operation, and production. The cost of a wood modification process varies according to the type of wood modification. Table 2 summarises the different plant setup costs, operational and production costs for the leading commercial wood modification.

Jones and Sandberg (2020) reported that the global commercial production of modified wood is dominated by thermal modifications which produces $1,110,000 \mathrm{~m}^{3} /$ year. Whereas, acetylation accounts for $120,000 \mathrm{~m}^{3} /$ year and furfuryation $45,000 \mathrm{~m}^{3} /$ year. Heräjärvi et al. (2020) projected the increase in production for ThermoWood $^{\circledR}$ forecast up to 2030. Although the cost for plant set up, the operational and production of modified wood is slightly higher than the conventional wood, it is still profitable to run the modified wood plant due to its high demand and still less supply of modified wood worldwide.

\subsection{Environmental issue}

It is essential to consider the environmental impact when adopting wood modification. Even though the wood modification aims to produce modified wood that would not cause harm any more significantly than natural wood during its life cycle, the process during the wood modification might be harmful to the health

Table 2. The cost of commercial wood modification

\begin{tabular}{|c|c|c|c|}
\hline $\begin{array}{l}\text { Wood modification } \\
\text { process }\end{array}$ & Plant set up cost & Operational cost & Production cost \\
\hline ThermoWood $^{(\mathbb{R}}$ & \$1 million installations (Hill, 2006) & $\mathrm{N} / \mathrm{A}$ & $\mathrm{N} / \mathrm{A}$ \\
\hline Plato $^{\circledR}$ & $\begin{array}{l}\text { Capital investment of } \$ 12-17 \\
\text { million to set up a plant with a } \\
\text { capacity of } 75,000 \mathrm{~m}^{3} \text { (Hill, 2006) }\end{array}$ & $24 \$ / m^{3}$ (Hill, 2006) & $\begin{array}{l}180 \$ / \mathrm{m}^{3} \text {, which is high due to the } \\
\text { complicated process (Hill, 2006; Hill, } \\
2011 \text { ) }\end{array}$ \\
\hline Oil heat treatment & $\begin{array}{l}\text { Capital investment of } \$ 540,000 \text { for } \\
\text { a capacity of } 8,500 \mathrm{~m}^{3} / \mathrm{a} \text { (Rapp and } \\
\text { Sailer, 2000) }\end{array}$ & $\begin{array}{l}75-110 \$ / \mathrm{m}^{3} \\
\text { depending on oil loading } \\
\text { (Rapp and Sailer, 2000) }\end{array}$ & $\begin{array}{l}320-360 \$ / \mathrm{m}^{3} \text { based on costs for } \\
\text { untreated timber of } 250 \$ / \mathrm{m}^{3} \text { (Rapp and } \\
\text { Sailer, 2000) }\end{array}$ \\
\hline Acetylated wood & $\mathrm{N} / \mathrm{A}$ & $\mathrm{N} / \mathrm{A}$ & $\begin{array}{l}\text { Depending on the size of the plant (eg: } \\
\$ 0.32 / \mathrm{lb} \text { for } 8,000 \text { tons/year, } \$ 0.27 / \mathrm{lb} \text { for } \\
20,000 \text { tons/year, } \$ 0.20 / \mathrm{lb} \text { for } 100,000 \\
\text { tons/year (Rowell, } 2007 \text { ) }\end{array}$ \\
\hline
\end{tabular}

Remarks: The cost is according to the valuation done according to the reference cited. N/A data not available. 
Table 3. The health and environmental impact of commercial wood modification

\begin{tabular}{|c|c|c|}
\hline $\begin{array}{c}\text { Wood modification } \\
\text { process }\end{array}$ & Impact during processing & Impact during the service life \\
\hline ThemoWood $^{\circledR}$ & $\begin{array}{l}3 / 4 \text { wood production consumes energy (in terms of } \\
\text { electricity, gas, or biomass) since the treatment is } \\
\text { based on heat production, and no chemicals are added } \\
\text { (Ferreira et al., 2016). }\end{array}$ & $\begin{array}{l}\text { - Fulfil the criteria of M1 (the best quality and } \\
\text { emission class) class of Finnish emission } \\
\text { classification of building material (Ala-Viikari } \\
\text { and Mayes 2009) } \\
\text { - Life cycle assessment (LCA) approved for } \\
\text { ecological building material considering the } \\
\text { production activities and its disposal at the end } \\
\text { of the life cycle (Ala-Viikari, 2007) }\end{array}$ \\
\hline Plato $^{\circledR}$ & $\begin{array}{l}\text { The effort for productive energy utilization: } \\
\text { - A closed and circulated cooling water system } \\
\text { - Isolated equipment } \\
\text { - Flash unit that makes low pressure stem out of the } \\
\text { condensate of medium pressure steam } \\
\text { - During winter, heating is done by pumping the } \\
\text { condensate of low-pressure steam through radiators }\end{array}$ & $\mathrm{N} / \mathrm{A}$ \\
\hline Oil heat treatment & $\begin{array}{l}\text { Low environmental impact heat is introduced in the } \\
\text { treatment system, and smokes from wood can be retrieved, } \\
\text { condensed, and purified (Candelier et al., 2016) }\end{array}$ & $\begin{array}{l}\text { Wood can be recycled without harmful impact } \\
\text { on the environment (Candelier et al., 2016) }\end{array}$ \\
\hline $\operatorname{Accoya}^{\circledR}$ & $\begin{array}{l}\text { Low emissions compared to other typical building } \\
\text { materials on a cradle-to-gate basis, such as aluminium, } \\
\text { steel, PVC, concrete and ceramic tiles. The embodied } \\
\text { emission of Accoya }{ }^{\circledR} \text { are better than sustainably } \\
\text { source woods and offer significant improvements } \\
\text { against unsustainably sourced materials like plastics } \\
\text { and metals (Trueman 2013). }\end{array}$ & $\begin{array}{l}\text { - Lower carbon footprint than steel, concrete, and } \\
\text { unsustainably source hardwood, and it is } \\
\text { competitive in terms of carbon footprint with } \\
\text { sustainably source hardwood (Bongers and } \\
\text { Uphill 2019) } \\
\text { - } \mathrm{CO}_{2} \text { negative LCA over a full life cycle } \\
\text { (Mantanis, 2017) }\end{array}$ \\
\hline Kebony ${ }^{\circledR}$ & $\begin{array}{l}\text { Use of furfuryl alcohol obtained from renewable } \\
\text { hydrolyzed biomass waste and improvement of the } \\
\text { polymerization process (Gérardin 2016) }\end{array}$ & $\begin{array}{l}\text { It is recognized as exempt from the Biocidal } \\
\text { Products Directory (BPD), given the absence of } \\
\text { active compounds in the process (Jones, 2007). }\end{array}$ \\
\hline
\end{tabular}

Remarks: N/A data not available

and environment. Table 3 summarises the effect of commercial wood modification on health and the environment.

Apart from the direct impact of wood modification on the environment, a few other environmental factors should be considered: the risk of leaching and end-oflife of wood that will be further discussed. Most importantly, the management of discarded treated wood products should be considered when evaluated to adopt a wood modification process as part of its LCA.

\subsubsection{Risk of leaching}

The oil-type modification sometimes oozes the oil on the surface of the modified wood. It may occur directly after treatment, or more complex leaching may happen in service when it is exposed to sunlight. This concern is best addressed through rigid control of the process, including avoiding over-treatment and adopting post-treatment conditioning methods, such as final vacuum, steaming, and expansion baths. Usually, the volume of oil that leaches out of the wood is negligible, but it can appear significant if it spreads on the water surface. Wood with a visible oily surface should not be used in sensitive environmental conditions or in uses that are likely to engage human contacts like decking and handrails (Archer and Lebow 2006). 
Apart from that, wood is one of the primary components of compostable organic products, for example, soil conditioners, compost, and mulches. Australia Standard AS 4454 states that these products should comply with the National Health Standard or local Environmental Protection Authority. The requirements also include that any clean wood waste can be processed if no more than $5 \%$ by volume of load contains chemical or organic contaminants (Daian and Ozarska, 2009). This is due to the risk of leaching in surface and groundwater, especially by chemically modified wood (Townsend et al., 2004). Therefore, treated products cannot be re-used in the animal products sector (Daian and Ozarska, 2009).

\subsubsection{End-of-life}

Modified wood waste should not be more challenging to handle as the modification process does not introduce any environmentally harmful or risky chemicals into the wood. Therefore, if the waste management of modified wood products results in hazardous waste, it is not caused by modification, but other reasons such as surface treatment or adhesives (Heräjärvi et al., 2020). European Parliament has established a guide to prolong the wood's service lifespan after it is approaching its end-of-life. It follows this hierarchy: wood-based products, re-use, recycling, bioenergy, and disposal. However, due to the modified wood characteristics, not all approaches can be applied to modified wood.

Wood products can be re-used either for the same purpose or a less demanding purpose after simple reshaping. Besides, wood damage sometimes occurs in a limited area, but the entire structure is replaced. In return, it will recover the cladding or decking materials in good condition for second-hand markets and recycling (Heräjärvi et al., 2020). Re-use is a desirable option if the secondary use is appropriate for the product or consistent with its original use (Archer and
Lebow 2006).

Even if the wood products are not qualified for further use, they can still be reprocessed as fibrous materials for making new wood-based products in part of the wood's recycling process. Compared to unmodified wood, modified wood characteristics include odour, combustibility and mechanical performance, low equilibrium moisture content, and slow rate of biodegradation. These characteristics are based on the modification treatment applied. Consequently, re-use and recycling of modified wood should be considered separately for each modified wood product category (Heräjärvi et al., 2020).

Next in the hierarchy is bioenergy. If recycling is not possible, wood products can still produce energy through direct combustion or conversion to gaseous or liquid fuel before burning. However, for chemically modified wood, there might be potential problems with air emission and ash generation. Thus, it is not applicable (Townsend et al., 2004).

The last hierarchy is landfilling, which is the least favoured end-of-life scenario but the cheapest option (Archer and Lebow 2006). Nevertheless, landfilling modified wood is restricted in some countries because of concerns regarding the high potential for surface and groundwater contamination. Most landfills have a leachate management system to reduce contamination and accept treated modified wood waste even though it may come with a cost. In Australia, several Australian state governments increase landfill levies to show stricter landfill policies and make the landfilling of waste unaffordable compared to the recycling industry. Therefore, due to the limited end-of-life of modified wood, the development of alternative disposal options is highly encouraged, including cogeneration, construction/demolition facilities, and more reliable recycling programs to extend landfill life (Morrell, 2004). 


\subsection{Barriers to Adoption}

Apart from the previously mentioned challenges to adopt the wood modification process in Australia, there are also several other barriers to implementation. The first barrier is the lack of technical knowledge in the wood modification process to establish a suitable process for the Australia wood industry. Other than that, differences between states in Australia regarding the availability of wood resources, regulatory requirements, appropriate processing systems, and local market needs should be considered and could present a barrier to adoption. Thus, these challenges and barriers can be tackled via feasibility studies or technical investigations to assess the opportunity requirements and market needs.

\section{RESEARCH and DEVELOPMENT (R\&D) for WOOD MODIFICATION in AUSTRALIA}

The wood industry is separated into two main branches: the first and second processing of wood. The first processing comprises forestry, sawmills, board industry, energy conversion, and pulp and paper industry. The second wood processing is part of the sawmilling industry characterized as production-oriented and adds manufacturing value to the sawn timber to fabricate different wood products. The R\&D of wood modification is part of the wood product industry, including the processing chain and manufacturing system (Salim and Johansson, 2016).

Innovation has received much attention from the researchers; however, the topic has only been explored briefly for the forest sector. Prior studies on innovation in the forest industry by Hovagaard and Hansen (2004) recognized distinct categories: product, process, and business system innovation. Innovation research in the forest sector is currently expanding, and the wood industry's innovation is receiving much attention from the researchers (Stendahl et al., 2013). R\&D activities in wood modification can be considered a product innovation that is explained as introducing a good service that is new or significantly improved concerning its properties or expected application. There are many ways how R\&D could be done many ways, but the three essential steps that could be done to study the wood modification process in Australia are feasibility studies, long-term investigation, and technology comparison.

\subsection{Feasibility Studies}

Information on products, markets, logistics, and wood resources availability is needed to conduct the feasibility study on wood modification in Australia. It would involve wood industry players and economists to study the business and financial feasibility and engineers for the technical feasibility.

A comprehensive feasibility study can be done on the locally modified wood, but this cannot be done due to Australia's non-existing wood modification process. Therefore, the application of ThermoWood ${ }^{\mathbb{R}}$ to Australian-grown P. radiata in New Zealand could provide a benchmark to develop a similar wood modification in Australia. However, some specific information is necessary, such as resource availability, consumer demand, market size, estimated prices, and the potential to meet Hazard Class $\mathrm{H} 3$ requirements that should be conducted in the Australia setting.

Besides, while developing the design concepts, it should be ranked in terms of potential cost, benefits, and risk. Strength, weakness, opportunities, and threats (SWOT) analysis is an example of a simple analysis that can be made with key findings from the study to discuss and conclude with the recommendation of a feasible process (Bartels, 2011). 


\subsection{Laboratory Investigations}

Laboratory investigations are pilot studies of the modification process on the Australian wood species that can be done on the laboratory scale. A pilot study is important to validate the idea ( $\mathrm{Pa}$ et al., 2008). An initial pilot study using a smaller sample (1-meter length) would help determine the chosen modification process's characteristics. Process variables might need to be revised during this laboratory test until the optimum, realistic and workable process is achieved to match the characteristic improvement needed. Besides, the pilot test can help assess the likelihood of success and identify the problem with the method (Lee, 2017).

Once the modification process is succeeded on the laboratory scale, a full-scale trial using $2.4 \mathrm{~m}$ sample lengths would help verify the processing parameters to achieve the same intended characteristics. Samples at this size also would display if there were any macro-scale effects from the modification. After successfully validating the modification process, an in-depth feasibility study would be conducted to assess the economic and environmental impact of the proposed treatment.

\subsection{Technology Comparisons and Transfer}

The ability to evaluate the recommended process with real data and settings is vital. This can be done using a technology assessment model, for example, WoodScape that has been developed for the New Zealand setting. The model provides a precise assessment of technology comparisons using data like processing costs such as capital and feedstock cost, product and by-product prices, labour, energy inputs, and other consumable costs like catalyst and solvents (Hill, 2006). A clear understanding of product operations and prices are needed to develop a similar model for modified wood in Australia. Nonetheless, plentiful data for the Australian setting are still unavailable.
Technology transfer is transferring technology from a person or organization that owns or holds it to another. Technology transfer is essential because this could help to accelerate the R\&D of a new product. For example, a thermal modified wood that has been perfected by an Estonian company called Thermory is available in Australia from local suppliers like InStyle, Timber Products and Australian Timbers. Instead of directly importing the wood products, the Australian could learn from the Thermory how to successfully treat the wood.

\section{PRODUCT DEVELOPMENT for WOOD MODIFICATION in AUSTRALIA}

New product development is a significant process but challenging to perform effectively. Thus, most new products or applications are either terminated or fail commercially (Metzner, 2018). Several considerations are required to ensure the success of the implementation and development of wood modification technologies in Australia, including market opportunities, environmental benefits, industry and regulatory structures, and co-operation between companies and marketing aspects.

\subsection{Market Opportunities}

In the Asia-Pacific region, the market for wood is expected to rise, with demand forecasted in 2020 will be higher than Western Europe's demand. Makowski (2014) outlines the strengths and opportunities for the Australian wood industry (Table 4).

Much focus on market opportunities is controlled by the commodity wood products, with high-value applications those suitable for modified wood products only covering a small part. Nonetheless, modified wood products would be utilized in the built environment for application like cladding, window joinery, 
Table 4. strength and opportunities for the Australian wood industry (Makowski, 2014)

\begin{tabular}{l|l}
\hline \multicolumn{1}{c|}{ Strength } & \multicolumn{1}{c}{ Opportunities } \\
\hline \hline $\begin{array}{l}\text { - Located in the Asia-Pacific region, which is a significant } \\
\text { growth area. }\end{array}$ & $\begin{array}{l}\text { - Export for value-added products. } \\
\text { - Operate with fully integrated processing using established business } \\
\text { models by executing new models to improve the market. }\end{array}$ \\
- Excellent wood resources and land availability. & - Update facilities to increase asset productivity. \\
- Competitive wood price. & - Provide customized export solutions, including the product, \\
- The reasonably strong Australian economy. & marketing, and supply chain. \\
- Well-known industry players with business models and concepts.
\end{tabular}

and other outdoor applications, including commercial decking and other commercial applications. Besides, there would be other potential products such as furniture making. Modified wood would cover these niches by promoting the improvement and modification of anti-bacterial characteristics, anti-scratch, and effortless to clean.

ABARES projected that the demand for wood products is forecast to rise by $30 \%$ by 2050 , mainly driven by sawn wood demand. Even though there is no data available on the present market for imported and modified wood from Australia, these products will be most suitable for higher-value applications in the built environment, including interiors. However, the application could be more diverse. Certain modified wood materials could compete with natural, durable hardwoods such as Intsia sp. and Tectona grandis and Australian hardwoods like E. marginate and E. pilularis.

The construction of dwellings is a significant market for wood products and an essential driver of economic growth in the wood sector. A statistic done by ABARES (2019) shows that the overall total dwelling commencements show an increasing trend over the years, which gives confidence that the market for building materials will also increase in demand. Other activities in building projects are restoration. Modified wood products could be used in residential restoration projects, for example, decking or cladding substitutes and outdoor living spaces.

Currently, the demand for modified wood products in Australia is indefinite, even though the modified material is imported from other countries. However, there is a tendency for increased user expectations for residential products' performance, including lesser functional and appearance defects like distortion, splitting, checking, and colour change. Whittle et al. (2019) assume that current technologies will remain in place; however, innovative products' importance will increase over time. This would provide opportunities for the forestry sector with new products that could change Australia's domestic wood processing industry structure.

\subsection{Environmental Benefit}

Several environmental benefits for wood modification technologies were discussed before, including lower toxicity, increased service life, fewer maintenance requirements, lower environmental impact, and carbon footprint. Additionally, modified wood is usually sourced from sustainable plantations compared to precious natural forest hardwoods. If the modified wood is locally produced, the transportation distance can be lowered compared to imported hardwoods.

LCA is an environmental impact assessment on a product that includes its use, life, degradation, acidification, and eutrophication. For wood modification, LCA would include inputs, for example, raw materials, energy, chemicals, manufacturing activity, plant construction, and output like waste, emissions, and effluents (Hill, 2006). Currently, LCA is already con- 
ducted on modified wood products, and the data are needed in the Environmental Product Declaration (EPDs) for the products to enter European markets. In addition, international standards (ISO 14040, 14044) specify what LCA should be managed. However, the later standard, which is ISO 14025, does not measure the effect of end-of-life disposal and thus, does not consider the environmental significance presented by modified wood products.

Hill and Norton (2014) showed the comparison of adopting LCA and EPD by providing a convincing study for wood products according to the raw material source, long-term ability to sequester carbon, and disposal techniques to extract energy. Currently, two EPDs for modified wood are available for Accoya ${ }^{\circledR}$ and Kebony ${ }^{\circledR}$ and LCA for ThermoWood ${ }^{\circledR}$. According to the same study, the life span needed to balance the products' environmental impact is 2.5 times higher for Accoya ${ }^{\circledR}$ and Kebony ${ }^{\circledR}$ than unmodified wood. This should be achievable due to the durability and service life enhancement that the modified wood could accomplish. The evaluation does not comprehend the maintenance cycle that would extend the service life of the modified wood.

Another metric that can attract consumers is the embodied energy in building materials. Consumer nowadays is more interested in "green" building materials that could lower the carbon footprint and environmental impact. Embodied energy can be found in two forms: (1) initial (i.e., the quantity of non-renewable energy used in the production of the material) and (2) recurring (i.e., the amount of energy used to maintain the material during service) (Hill, 2006). However, it is not easy to accurately calculate the embodied energy in a material. In terms of wood products, it includes the energy consumed during growing, managing, harvesting, and transporting wood resources. This led to difficulties in analyzing the same materials and comparing between the different materials. As consequence, there are no databases of embodied energy for modified wood.

\subsection{Regulatory Structures}

One of the main issues that should be tackled in Australia is the wood industry players are not interested in replanting their wood after the current rotations are harvested. In return, it would create problems with the shortage of raw materials in the future. The plantation forestry will not be replanted because the current policy, the investment revenues from plantation forestry are sub-optimal. This is due to the price for wood that is unsustainably low, especially for long rotation wood.

Besides, most of the investments in new plantations are from privately funded companies in which these companies are looking for short-term returns on investment from plantation trees grown explicitly under silviculture practices to produce small-diameter pulp logs for paper products that generally only take about 10 - 15-year rotation (Lott and Gooding, 2007). The uncertainties of economic returns for investors if they invest in plantation sawlogs are due to the possible changes in technology, site and environment, pests and diseases, and high cost associated with the extended period. Thus, ABARES applied a pre-tax discount of $7 \%$ to all future returns and costs associated with timber plantations and wood processing investment projects. This incentive is one of the many incentives introduced by the government to encourage these private companies to manage plantation wood for longer rotation (Whittle et al., 2019).

Regulatory bodies could help the plantation industry by introducing policies that could support the industry, especially in their efforts to produce renewable and carbon-positive products manufactured from wood. The government can do other support by helping them financially and supporting product development to increase the plantation wood value. 


\subsection{Co-operation between Companies}

In wood modification, a distinct business benefits from working with other companies in the wood modification sector, especially when the challenge is considered too large to be taken care of by a single company. Better knowledge in terms of characteristics and functionality of wood, technology for wood processing, control of raw material, and production flow, and also development of product standards were all suited for broad collaboration. Thus, industry-wide collaboration, particularly large companies' initiative to advocate for the smaller companies, is crucial (Stendahl et al., 2013). This idealistic viewpoint is possible through the ThermoWood ${ }^{\circledR}$ network in Finland, where product development's best interest is placed ahead of individual company domination. Even though some companies within the ThermoWood ${ }^{\mathbb{R}}$ association operate significantly more extensive than others, the collective operation's benefits have been proven.

Nowadays, even research in wood modification is no longer performed by a small group of researchers but by a research community worldwide that has grown considerably over the years (Militz, 2020). For example, the International Research Group of Wood Protection has considered the need for a collective approach in marketing and development for wood modification, demonstrating the increasing awareness of many companies in the increasing importance of nontraditional methods to increase timber species' durability. The co-operation between the traditional wood preservation industry and wood modification needs to be repaid by creating a new market of modified wood, not by capturing the market currently held by preserved wood. The interactions between companies that work in wood modification, wood preservation, coating technologies, product manufacturers, and architects will be interactions that will provide insights on technologies to enter today's market. It is a financially un- sound option to develop a complete chain from wood treatment to the final product for each process; thus, it is better to use each sector's expertise for the overall benefit (Jones, 2007).

\subsection{Marketing Aspects}

For a new product to successfully progress from idea to product launching, the marketing activities should be an integral and essential part of it (Metzner, 2018). Unfortunately, marketing activity in the wood industry are frequently skipped over and/or poorly executed. Only through a well-planned and orchestrated marketing policy, a product can succeed in today's aggressive marketplace. The main marketing area that should be accessed is (1) identifying the market area, (2) identifying the main competitors, (3) understanding the product, (4) conducting sales pitches, and (5) making a profit.

Several years ago, the wood modification process was considered a replacement for all treatments and alternative materials. This has been re-evaluated to the point that selected wood modification techniques are aimed towards specific markets . Information in Table 5 could represent an insight into the perceived areas where selected wood modification techniques could be successfully applied, and it is also important to realize that the listed modification methods are not the only options. The table should be used to provide an idea into which market modified products should be targeted. Once the product range has been identified, it is necessary to undertake a SWOT analysis. The aim is to rationally evaluate the potential of a product/ method within the selected market.

Other than that, using a brand name instead of 'modified wood' represents a significant step forward, providing a more recognizable product. The primary commercial modified wood like ThermoWood $^{\mathbb{}}$, Accoya ${ }^{\mathbb{R} \text {, }}$ and Kebony ${ }^{\circledR}$ are all using the brand name. Besides, 
Table 5. Overview of perceived market opportunities for modified wood (Westin, 2001)

\begin{tabular}{l|l}
\hline \multicolumn{1}{c|}{ Type of product range } & \multicolumn{1}{c}{ Suitable wood modification } \\
\hline \hline Garden furniture & Thermally modified wood \\
\hline Window frames & Acetylated wood \\
\hline Exterior door and frames & Acetylated wood \\
\hline Flooring & Several types of modified wood \\
\hline Wet room and façade panels & Acetylated wood \\
\hline Building products & Acetylated/thermal modified wood \\
\hline Automotive/nautical applications & Furfurylated wood \\
\hline Use by architect/government organizations & Acetylated/thermal modified wood \\
\hline
\end{tabular}

it provides the perception of a new timber species, recognized as a marketing advantage. The use of a brand name may be further enhanced with strong environmental credentials.

\section{THE FUTURE of WOOD MODIFICATION in AUSTRALIA}

It is only inevitable that wood modification will continuously be developed in Australia and elsewhere. Australia needs to catch up with the European countries to develop its modification process that is appropriate for its wood resources. However, it has taken several decades for wood modification in Europe to achieve this point, with severe commercial development established in the past 20 to 25 years. Therefore, it is reasonable for the wood industry in Australia and elsewhere to take time to develop its modification process. Nevertheless, suggestions from the existing application should be taken seriously so that Australia's wood industry would work progressively. For example, Australia can learn from their neighbour country, New Zealand, using their developed wood modification process.

The early stage of developing modified wood would require substantial capital, especially in setting up the production plant. It also would take around 5 to 10 years or longer before they become profitable. Thus, the government needs to play its role in supporting the industry. When the industry starts to make a profit, it is also likely that the modified materials will be widely available and will reduce production costs. In return, it will make the modified wood more affordable for consumers.

Opportunities to expand modification technologies in Australia are very positive as users are growing in demand for products with excellent performance. Simultaneously, the local councils need to consider the environmental footprint, sustainability, and long-term performance of their building, infrastructure, and facilities to encourage green materials. Besides, wood modification technologies are established with consideration and focus on raising local wood species that can perform well at the commodity level into high-value products. Another consideration that will raise the significance of wood modification in Australia is the reduced supply of naturally durable wood locally or imported from developing countries as regulations and agreements are getting strict. It is a well-known fact that the timber supply is declining at a faster rate. Furthermore, with the increasing utilization of Eucalyptus plantation wood in Australia, an effort should be taken so that the low-grade plantation wood in Australia can be increased significantly to reduce the dependency on imported wood. 


\section{REFERENCES}

ABARES. 2018. Australia's State of Forest Report. Amer, M., Kabouchi, B., El Alami, S., Azize, B., Rahouti, M., Famiri, A., Fidah, A. 2019. Water sorption/desorption kinetics and convective drying of Eucalyptus globulus wood. Journal of the Korean Wood Science and Technology 47(5): 557-566.

Ala-Viikari, J. 2007. The Activities of Finnish ThermoWood Association to Commercialize ThermoWood. In the Third European Conference on Wood Modification, pp. 3-10.

Ala-Viikari, J., Mayes, D. 2009. New generation ThermoWood®-How to take ThermoWood $₫$ to the next level. In Proceedings European Conference on Wood Modification.

Archer, K., Lebow, S. 2006. Wood preservation. In Primary Wood Processing, Springer, Dordrecht, pp. 297-338.

Balboni, B.M., Batista, A.S., de Aguiar Rodrigues, R., Garcia, J.N., 2020. Relationship between strength and density in juvenile and mature Eucalyptus sp. wood. Brazilian Journal of Animal and Environmental Research 3(3): 983-991.

Bartels, T. 2011. Technical and commercial feasibility study for Accoya wood in Dutch civil waterworks constructions (Doctoral dissertation, Van Hall Larenstein).

Beadle, C., Volker, P., Bird, T., Mohammed, C., Barry, K., Pinkard, L., Wiseman, D., Harwood, C., Washusen, R., Wardlaw, T., Nolan, G. 2008. Solid-wood production from temperate eucalypt plantations: a Tasmanian case study. Southern Forests 70(1): 45-57.

Bongers, F., Uphill, S.J. 2019. The potential of wood acetylation.van de Kuilen, J.-W. and Gard, W.[eds.] ISCHP, pp. 49-57.

Brown, A.G., Beadle, C.L. 2008. Plantation Eucalypts for High-Value Timber: Enhancing investment through research and development Publication No.
08/Project No. CVF-2A. Canberra, RIRDC Joint Venture Agroforestry Program.

Candelier, K., Thevenon, M., Petrissans, A. 2016. Control of wood thermal treatment and its effects on decay resistance: A review, Annals of Forest Science. pp. 571-583. doi: http://dx.doi.org/10.1007 /s13595-016-0541-x

Daian, G., Ozarska, B. 2009. Wood waste management practices and strategies to increase sustainability standards in the Australian wooden furniture manufacturing sector. Journal of Cleaner Production 17(17): 1594-1602.

de Cademartori, P.H.G., Missio, A.L., Mattos, B.D., Schneid, E., Gatto, D.A. 2014. Physical and mechanical properties and colour changes of fast-growing Gympie messmate wood subjected to two-step steam-heat treatments. Wood Material Science and Engineering 9(1): 40-48.

Derikvand, M., Nolan, G., Jiao, H., Kotlarewski, N. 2017. What to do with structurally low-grade wood from Australia's plantation eucalyptus; building application?. BioResources 12(1): 4-7.

Donnelly, R., Fynn, R., Shield, E. 2003. The global Eucalyptus wood products industry - A progress report on achieving higher value utilization. DANA Publishing Limited. New Zealand.

Downham, R., Gavran, M. 2019. Australian plantation statistics 2019 update. Aust Gov Dep Agric Water Resour Canberra, Aust, 12.

Drysdale, D. 2011. An Introduction to Fire Dynamics (3rd Ed.). Chichester: John Wiley \& Sons.

Dunningham, E., Sargent, R. 2015. Review of new and emerging international wood modification technologies. Project No: PNA350-1415. Forest and Wood Products Australia Limited. 978-1-925213-24-9, p. 56.

Esteves, B., Pereira, H. 2009. Wood modification by heat treatment: A review. BioResources 4(1): 370-404. 
Ferreira, J., Esteves, B., Nunes, L., Domingos, I. 2016. Life Cycle Assessment as a tool to promote sustainable Thermowood boards: a Portuguese case study. International Wood Products Journal 7(3): 124-129.

Gérardin, P. 2016. New alternatives for wood preservation based on thermal and chemical modification of wood: A review, Annals of Forest Science, pp. 559-570. doi: http://dx.doi.org/10.1007 /s13595-015-0531-4

Hadi, Y.S., Massijaya, M.Y., Zaini, L.H., Pari, R. 2019. Physical and mechanical properties of methyl methacrylate-Impregnated wood from three fast-growing tropical tree species. Journal of the Korean Wood Science and Technology 47(3): 324-335.

Heräjärvi, H., Kunttu, J., Hurmekoski, E., Hujala, T., 2020. Outlook for modified wood use and regulations in circular economy. Holzforschung 74(4): 334-343.

Hillis, W.E. 1987. Heartwood and tree exudates. Springer Verlag, Berlin, Germany.

Hill, C.A.S. 2007. Wood modification: chemical, thermal and other processes (Vol. 5). John Wiley \& Sons.

Hill, C.A.S. 2011. Wood modification: An update, BioResources 6(2): 918-919.

Hill, C.A.S., Norton, A. 2014. The environmental impacts associated with wood modification balanced by the benefits of life extension. The Seventh European Conference on Wood Modification, September 2014, Lisbon, Portugal.

Homan, W., Tjeerdsma, B., Beckers, E., Jorissen, A. 2000. July. Structural and other properties of modified wood. In World Conference on Timber Engineering Vol. 5.

Hovgaard, A., Hansen, E. 2004. Innovativeness in the forest products industry. Forest Products Journal 54(1): 26-33.

Innes, T., Greaves, B., Washusen, R., Nolan, G. 2008.
Determining the economics of processing plantation eucalypts for solid timber products. Project number: PN04.3007 (trans: Improvement RCa). Forest and Wood Products Australia, Melbourne.

Jiang, T., Gao, H., Sun, J., Xie, Y., Li, X. 2014. Impact of DMDHEU resin treatment on the mechanical properties of poplar. Polymers and Polymer Composites 22(8): 669-674.

Jones, D. 2007. The commercialization of wood modification-past, present and future. In Proceedings of the 3rd European Conference on Wood Modification. Cardiff, UK, pp. 436-439.

Jones, D., Sandberg, D., Kutnar, A. 2018. A Review of Wood Modification across Europe as Part of COST. pp. 24-31.

Jones, D., Sandberg, D. 2020. A Review of Wood Modification Globally-Updated Findings from COST FP1407. Interdisciplinary Perspectives on the Built Environment, 1.

Kim, H.S., Kim, S., Kim, H.J., Yang, H.S. 2006. Thermal properties of bio-flour-filled polyolefin composites with different compatibilizing agent type and content. Thermochimica Acta 451(1-2): 181-188. doi: https://doi.org/10.1016/j.tca.2006.09.013

Lahtela, V., Hamalainen, K., Karki, T, 2014. The Effects of Preservatives on the Properties of Wood after Modification (Review paper), Baltic Forestry 20(1): 189-203.

Lande, S., Westin, M., Schneider, M. 2008. Development of modified wood products based on furan chemistry. Molecular crystals and liquid crystals 484(1): 1-367.

Lee, M.D. 2017. Capacity Utilization of Small Scale Desalination Plant, Universiti Malaysia Sarawak.

Li, J., Li, B., Zhang, J. Zhou, X., 2019. Tannin Resins for Wood Preservatives: A Review. Research and Application of Materials Science 1(1): 48-53.

Lott, R., Gooding, G. 2007. Eucalypt plantations for solid-wood products in Southern Australia: A 
review of research investment needs. In: Plantation Eucalypts for high-value timber: Enhancing investment through research and development, 9-12 October 2007 Moorabin, Victoria.

Makowski, M. 2014. The Australian wood processing \& timber industry. Current operations, outlook and future opportunities through process and product innovation. Presentation given at Wood Innovations 2014, Melbourne Australia.

Mantanis, G.I., Şahin, H.T. 2017. Modification of wood by chemical processes: A review, in, International Symposium on New Horizons in Forestry, pp. 272-280.

Metzner, C. 2018. Strategies for continuous improvement and improved competitiveness for the sustainable bio-based industries. Master's Thesis, The University of Tennessee, Knoxville, TN, USA.

Militz. H. 2002. Thermal treatment of wood: European processes and their background. The International Research Group on Wood Preservation. Document No. IRG/WP 02-40241.

Militz, H. 2020. Wood modification research in Europe. Holzforschung 74(4): 333-333.

Morrell, J. 2004. Disposal of Treated Wood, Proceedings for the Environmental Impacts of PreservativeTreated Wood Conference, Gainesville, pp. 196-209. Nichols, J.D. 2010. Subtropical eucalypt plantations in eastern Australia, Australian Forestry 73(1): 53-62.

Nolan, G., Greaves, B., Washusen, R., Parsons, M., Jennings, S. 2005. Eucalypt Plantations for Solid Wood Products in Australia: A Review. Forest and Wood Products Research and Development Corporation, Melbourne, Project No. PN04.3002, pp. 1-130.

Pal, R., Sengupta, A., Bose, I. 2008, 'Role of Pilot Study in Assessing Viability of New Technology Projects: The Case of RFID in Parking Operations. Communications of the Association for Information Systems 23(1): 257-276.
Priadi, T., Sholihah, M., Karlinasari, L. 2019. Water absorption and dimensional stability of heat-treated fast-growing hardwoods. Journal of the Korean Wood Science and Technology 47(5): 567-578.

Rapp, A.O., Sailer, M. 2000. November. Heat treatment of wood in Germany-state of the art. In Proceedings of the seminar on production of heat-treated wood in Europe. 20: 2000.

Ramage, M.H., Burridge, H., Busse-Wicher, M., Fereday, G., Reynolds, T., Shah, D.U., Wu, G., Yu, L., Fleming, P., Densley-Tingley, D., Allwood, J., 2017. The wood from the trees: The use of timber in construction. Renewable and Sustainable Energy Reviews 68: 333-359

Rowell, R.M. 2005. Chemical modification of wood. Handbook of wood chemistry and wood composites, pp. 381.

Rowell, R.M. 2007. Chemical modification of wood. Handbook of engineering biopolymers, homopolymers, blends, and composites. Cincinnati, OH: Hanser Gardner Publications, Inc., 2007: pp. 673-691.

Salim, R., Johansson, J. 2016. The influence of raw material on wood product manufacturing. Procedia CIRP, 57: 764-768.

Sargent, R. 2019. Evaluating dimensional stability in solid wood: a review of current practice. Journal of Wood Science 65(1): 1-11.

Shi, J.L., Kocaefe, D., Zhang, J. 2007. Mechanical behaviour of Quebec wood species heat-treated using ThermoWood process. Holz als Roh-und Werkstoff 65(4): 255-259.

Stendahl, M., Roos, A., Hugosson, M. 2007. Product development in the Swedish and Finnish sawmilling industry-a qualitative study of managerial perceptions. Journal of Forest Products Business Research 4(4): 24.

Stendahl, M. 2009. Product development in the wood industry. Department of Forest Products. Uppsala, Sweden. 
Tondi, G., Thévenon, M.F., Mies, B., Standfest, G., Petutschnigg, A., Wieland, S. 2013. Impregnation of Scots pine and beech with tannin solutions: effect of viscosity and wood anatomy in wood infiltration. Wood science and technology 47(3): 615-626.

Townsend, T.G., Dubey, B., Solo-Gabriele, H. 2004. Assessing potential waste disposal impact from preservative treated wood products. Environmental Impacts of Preservative-Treated Wood, pp.169.

Townsend, T.G., Solo-Gabriele, H. eds. 2006. Environmental impacts of treated wood. CRC press.

Tepper, C. 2007. October. Site matching and establishing Eucalypt sawlog species in Southern Australia. In Proceedings of the Joint Venture Agroforestry Program Conference: Plantation Eucalypts for High-Value Timber: Enhancing Investment Through Research and Development, Moorabin, Victoria, Australia, Vol. 912.

Trueman, E. 2013. Accoya ${ }^{\circledR}$ wood cradle-to-gate carbon footprint update.
Unsal, O., Candan, Z., Buyuksari, U., Korkut, S., Chang, Y.S., Yeo, H.M. 2011. Effect of thermal compression treatment on the surface hardness, vertical density propile and thickness swelling of eucalyptus wood boards by hot-pressing. Journal of the Korean Wood Science and Technology 39(2): 148-155.

West, P.W. 2006. Growing Plantation Forests, Lismore, NSW. Australia, Springer-Verlag.

Westin, M. 2001. New products and new applications. Deliverable 23 of the Thematic Network for Wood Modification. E.U. Fifth Framework Program project G1RT-CT-2000-05002

Whittle, L., Lock, P., Hug, B. 2019. Economic potential for new plantation establishment in Australia. Department of Agriculture and Water Resources.

Wood, M.J., McLarin, M.L., Volker, P.W., Syme, M. 2009. Management of eucalypt plantations for profitable sawlog production in Tasmania, Australia. In Tasforests 18: 117-121. 